\title{
The interaction between ammonium and nitrate uptake in phytoplankton
}

\author{
Quay Dortch \\ Louisiana Universities Marine Consortium, Chauvin, Louisiana 70344, USA
}

\begin{abstract}
A basic tenet of nitrogen utilization in phytoplankton is that ammonium inhibits nitrate uptake. Consequently, it is generally believed that little or no nitrate uptake occurs at ammonium concentrations above ca $1 \mu \mathrm{M}$. A thorough review of field studies shows that the reduction of nitrate uptake rate in the presence of ammonium is rarely so severe, and that it is a highly variable phenomenon. To simplify quantification of the interaction between nitrate and ammonium uptake, it is proposed that it be divided into an indirect interaction, preference, and a direct effect, inhibition. In order to determine preference and inhibition it is necessary to measure uptake of each inorganic nitrogen source alone and in the presence of increasing concentrations of the other nitrogen source. Preference for ammonium uptake is manifested primarily in a higher $\mathrm{V}_{\text {max }}$ and lower $\mathrm{K}$, for ammonium uptake than for nitrate uptake and is accentuated by low light and low nitrogen availability. However, although ammonium is the preferred nitrogen source for uptake, growth rates on nitrate usually equal or exceed those on ammonium. Inhibition of nitrate uptake by ammonium is much more variable, but when separated from preference is less extreme. It is also enhanced by low light, but unlike preference, it is greater when phytoplankton are $N$ sufficient. Species differences are apparent for both preference and inhibition, but there are only enough data for preference to determine how it varies among algal groups. Finally, there are reports of low concentrations of ammonium stimulating nitrate uptake and of nitrate inhibiting ammonium uptake. Such unexpected interactions along with variations in preference and inhibition with species composition and environmental conditions may account for the variability observed in field studies and will not be explainable or predictable until more is known about the underlying biochemical mechanisms. Even though it is not possible at present to model nitrate uptake accurately because of uncertainty about the interaction between ammonium and nitrate uptake, it is quite evident that the simplistic view that nitrate uptake is reduced to zero if ammonium exceeds $1 \mu \mathrm{M}$ would often result in large underestimates of nitrate uptake and new production.
\end{abstract}

\section{INTRODUCTION}

It is generally believed that the rate of nitrate uptake by phytoplankton is severely reduced by the presence of ammonium. This effect is referred to either as 'inhibition' of nitrate uptake by ammonium or 'preference' for ammonium, and in its most extreme form it is believed to result in no nitrate uptake above a threshold ammonium concentration of ca $1 \mu \mathrm{M}$. Evidence for the negative effect of ammonium on nitrate utilization arises from 3 sources: (1) early laboratory studies of nitrate utilization in freshwater green algae (reviewed in Morris 1974), (2) early field studies in marine ecosystems (Table 1), and (3) theoretical considerations of the relative energy require- ments for the utilization of nitrate and ammonium, due to the number of electrons required to reduce nitrate to ammonium (Losado \& Guerrero 1979, Syrett 1981). In many of these early studies it was assumed that nitrate uptake (transport into the cell) and reduction were so tightly coupled that uptake of nitrate must be inhibited by ammonium because the enzyme nitrate reductase is strongly inhibited. It is now known that nitrate uptake and reduction are frequently uncoupled during transient conditions in marine phytoplankton (DeManche et al. 1979, Dortch et al. 1979, Collos 1982) and that nitrogen uptake and assimilation are so complex that it is difficult to explain the interaction between nitrate and ammonium uptake by one simple mechanism 


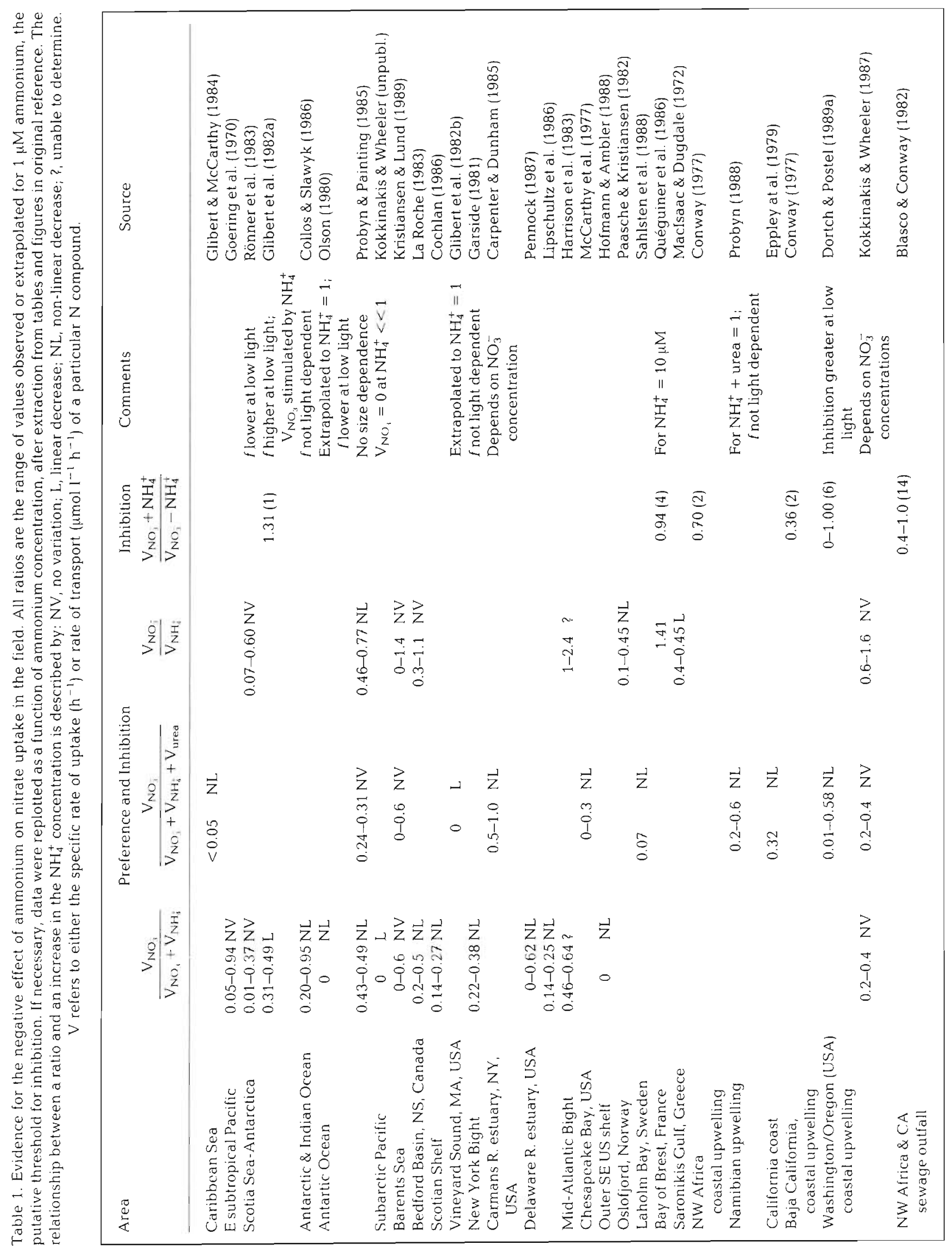




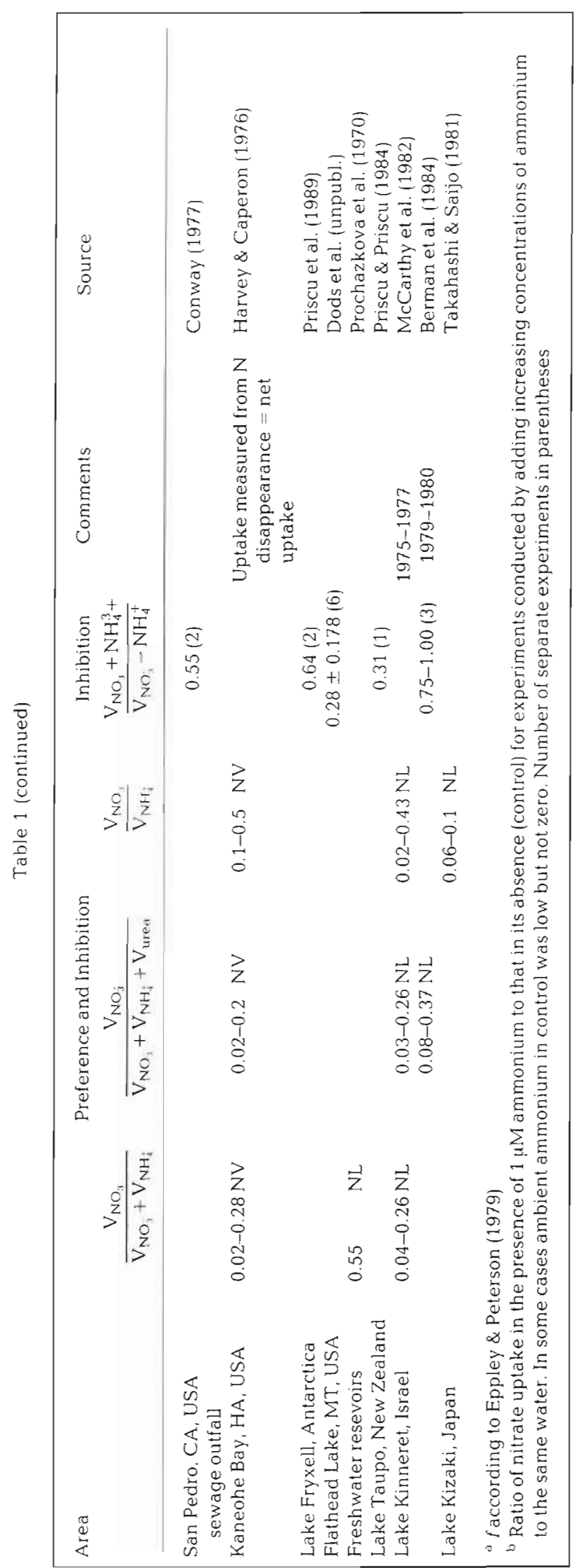

A thorough review of the literature, however, indicates that 'inhibition' or 'preference' is neither as universal nor as severe a phenomenon as is generally believed (i.e., ammonium does not always 'inhibit' nitrate uptake and even when it does, nitrate uptake rarely ceases entirely). In addition, as will be described in more detail later, it has also been reported that nitrate can sometimes inhibit ammonium uptake and that small amounts of ammonium may actually stimulate nitrate uptake. Furthermore, what is loosely called 'inhibition' or 'preference' is in fact several distinct processes, which are affected differently by ammonium and environmental conditions. Much of the confusion about the effect of ammonium on nitrate uptake may arise because most often it is the sum of these processes which is measured, especially in the field. With the renewed interest in measuring nitrate uptake as a means of estimating new production and flux of carbon out of the euphotic zone, it is time for a more rigorous examination of the interaction between nitrate and ammonium uptake. Until the process of nitrate uptake is better understood, it will not be possible to model the response of nitrate uptake to environmental conditions or to model its relationship to productivity.

The purpose of this review is 3 -fold. First, all of the available field data on the interaction between nitrate and ammonium uptake will be reviewed in order to assess the validity of the current paradigm. Then, the interaction will be redefined in terms of the 2 distinctly different processes involved, so that it can be more easily quantified. Finally, with these more rigorous definitions, the ammonium/nitrate interaction will be examined as a function of species identity, geographic location, and environmental variables using suitable published lab and field data. The goal is to develop a more realistic model of the interaction between ammonium and nitrate uptake which will allow more accurate prediction, measurement, and explanation of nitrate and ammonium uptake rates in natural phytoplankton assemblages.

\section{EFFECT OF AMMONIUM ON NITRATE UPTAKE IN THE FIELD}

The interaction between ammonium and nitrate uptake has been quantified by calculating 3 ratios at 1 $\mu \mathrm{M}$ ammonium from data compiled from as many areas as possible (Table 1): (1) nitrate uptake/total nitrogen uptake (f-ratio; Eppley \& Peterson 1979) with total uptake either including or not including urea uptake; (2) nitrate uptake/ammonium uptake; and (3) nitrate uptake in the presence of ammonium/nitrate uptake in the absence of ammonium. While the latter is the preferred method for reasons which will be discussed later, 
all 3 ratios, when estimated at 1 !M can be used to judge the severity of the effect of ammonium on nitrate uptake. The concentration of $1 \mu \mathrm{M}$ was chosen because it is most often cited as the threshold ammonium concentration that results in a pronounced decrease in nitrate uptake rate. The f-ratios with urea are included to maximize the data available, although the presence of urea complicates interpretation in terms of the interaction between nitrate and ammonium.

Several conclusions are immediately evident. (1) Sometimes nitrate uptake in the presence of $1 \mu \mathrm{M}$ ammonium is considerably lower than ammonium uptake, although rarely zero. (2) However, the degree to which nitrate uptake is affected by ammonium is quite variable and nitrate uptake at $1 \mu \mathrm{M}$ ammonium can equal or exceed ammonium uptake rates ( $\mathrm{N}_{\mathrm{NO}_{-}^{-}}$' $\mathrm{V}_{\mathrm{NH}_{\mathrm{i}}}>1$ ). In fact, sometimes nitrate uptake is not related to ammonium concentration (Goering et al. 1970. Harvey \& Caperon 1976, Rönner et al. 1983, Kokkinakis \& Wheeler 1987, Kristiansen \& Lund 1989). Furthermore, nitrate uptake may also be stimulated by ammonium (Glibert et al. 1982b). (3) The ratio of (nitrate uptake in the presence of $1 \mu \mathrm{M}$ ammonium)/ (nitrate uptake in the absence of ammonium), tends to show a less negative effect of ammonium than the other ratios in Table 1 This is because the $f$-ratio and nitrate/ ammonium uptake ratios combine several processes ('preference' and 'inhibition') involved in the nitrate/ ammonium interaction, whereas the ratio of nitrate uptake with and without ammonium measure only 'inhibition', as will be discussed in a following section. Other reports of simultaneous uptake of nitrate and ammonium (Conover 1975b, Kuenzler et al. 1979, Harrison et al. 1982, 1983, 1985, Price et al. 1985, Collos et al. 1989) and a preference for nitrate over ammonium (Warfar et al. 1983, Harrison et al. 1987) could not be readily tabulated in the format of Table 1 because the data necessary for comparison were not included.

Another common method of assessing the interaction of nitrate and ammonium uptake is to calculate the relative preference index (RPI) for a nitrogen source (McCarthy et al. 1977),

$$
\mathrm{RPI}_{\mathrm{NO}}^{-}=\frac{\frac{\mathrm{P}_{\mathrm{NO}}^{-}}{\Sigma \rho_{\mathrm{N}}}}{\frac{\left[\mathrm{NO}_{3}^{-}\right]}{[\mathrm{NN}]}}
$$

where $P_{\mathrm{NO}^{-}}=$the nitrate uptake rate $\Sigma_{\mathrm{N}}=$ the sum of the uptake rates measured for all nitrogen sources; $\left[\mathrm{NO}_{3}^{-}\right]=$ the ambient nitrate concentration; and $\left[\Sigma_{N}\right]=$ the sum of the concentrations of all the nitrogen sources measured. Values $<1$ indicate preference for ammonium and $>1$ preference for nitrate. There are a number of problems with this ratio which make it difficult to interpret. (1) It cannot be calculated if the ambient nitrate is undetectable, which is precisely the time when nitrate might be preferred, thus biasing conclusions. (2) The precision of the RPI is low because of the error which results from combining so many variables (Collos \& Slawyk 1986). (3) Its numerical value can change in response to ambient nitrogen concentrations without any changes in uptake rate, so it does not necessarily have a physiological or ecological basis (Paasche 1988). (4) This ratio is often treated as an indicator of inhibition, so that low values are interpreted as meaning that little or no nitrate uptake occurs, whereas in fact it is an indicator of preference and simply means that ammonium uptake proceeds at a faster rate than nitrate uptake (see following sections for further discussion). In general the $\mathrm{RPI}_{\mathrm{NO}_{3}^{-}}$is usually $<1$ (McCarthy et al. 1977. Paasche \& Kristiansen 1982, Furnas 1983, Glibert \& McCarthy 1984, Carpenter \& Dunham 1985, Cochlan 1986, Whalen \& Alexander 1986, Pennock 1987, Dortch \& Postel 1989a). However, in a very thorough study Harrison et al. (1987) compiled their data from many different areas (467 measurements), and obtained an overall $\mathrm{RPI}_{\mathrm{NO}}$ of 0.97 . Plotted by region it was significantly $>1$, indicating nitrate preference, for 2 areas (Mid-Atlantic Bight, Peru), $<1$, indicating preference for ammonium, for 3 studies (S. California Bight, Scotian Shelf, Bedford Basin), and not significantly different from 1, for 3 studies (E. Canadian Arctic 1978, 1980, Vineyard Sound). Less extensive data sets suggest that the $\mathrm{RPI}_{\mathrm{NO}_{3}}$ approaches 1 when nitrate concentrations are high during the spring or as a result of mixing or upwelling (Carpenter \& Dunham 1985, Pennock 1987. Dortch \& Postel 1989a) or when phytoplankton are nitrogen deficient (McCarthy et al. 1977, Paasche \& Kristiansen 1982, Furnas 1983, Glibert \& McCarthy 1984, Cochlan 1986, Whalen \& Alexander 1986).

It has been hypothesized that nitrate will be preferred or simultaneous uptake will be more likely in benthic diatoms (Admiraal et al. 1987), coastal phytoplankton (Pennock et al. 1987), large diatoms (Malone 1980. Kokkinakis \& Wheeler 1987), or phytoplankton exposed to frequent high pulses of both nitrate and ammonium (Maestrini et al. 1986, Quéguiner et al. 1986). There are too few data in Table 1 to generalize about the effect of species preferences on regional variability, although the question of species preference will be considered in later sections when laboratory data are reviewed. Similarly, some of the data in Table 1 suggest that environmental conditions, such as light and nitrogen availability, should influence the interaction. Since it is difficult to quantify these factors in the field, their influence will also be determined from a review of laboratory results.

In conclusion, the original paradigm that nitrate uptake decreases to very low levels or is effectively zero at ammonium concentrations greater than $1, \mu \mathrm{M}$ is 
not supported by the available data. Furthermore, there is enormous variability in the degree to which ammonium does affect nitrate uptake which is not adequately explained by current models.

\section{REDEFINING THE INTERACTION BETWEEN AMMONIUM AND NITRATE UPTAKE}

The interaction between ammonium and nitrate uptake can be simplified by dividing it into 2 distinct processes: an indirect interaction, which will be termed preference, and a direct interaction, which will be called inhibition. These 2 interactions are not mutually exclusive; one or both can occur in phytoplankton. They are, however, influenced differently by environmental conditions, and vary in importance from species to species. It is reasonably easy to measure preference and inhibition separately in the lab, but much more difficult in the field because it is necessary to measure uptake of nitrate and ammonium in the absence of the other, a condition rarely met in the field.

Preference for ammonium over nitrate means that ammonium is more readily utilized than nitrate. Preference is independent of the ammonium concentration, and, in fact, can only be assessed by measuring nitrate uptake in the absence of ammonium and ammonium uptake in the absence of nitrate. Although this review is concerned primarily with interactions between nitrate and ammonium uptake, uptake measurements, especially in the field, are often made over time periods long enough to encompass uptake, assimilation, and growth. Since the interaction between these processes is complex, preference for one nitrogen source could be manifested in a variety of ways. The maximum rate $\left(V_{\text {max }}\right)$ for uptake of one nitrogen source may be higher or the half-saturation constant $\left(\mathrm{K}_{\mathrm{s}}\right)$ may be lower than for the other nitrogen source. There could be a time lag in either the uptake or assimilation of one nitrogen source that is not observed with the other. Finally, growth rates might be greater on one nitrogen source than the other. Any one or all of these indicate a true preference for a particular nitrogen source. While uptake or growth on the preferred nitrogen source would be greater, uptake and growth on the other nitrogen source can still occur, sometimes at rapid rates, and independent of the concentration of the preferred nitrogen source.

Inhibition results when the presence of one nitrogen source prevents or reduces the uptake of the other. It can only be quantified by comparing the uptake rate in the absence of the inhibiting nitrogen source with uptake rates in the presence of increasing concentrations of the inhibitor. Thus, unlike preference, inhibition is dependent on the concentration of the inhibitor. Although inhibition is a term with a very precise biochemical meaning related to a particular mechanism of interaction, no such mechanism is implied here by its use. Despite considerable research in this area, no mechanism(s) has been proposed which can adequately explain the complex interaction. Separating preference from inhibition is a first simplification since the mechanisms involved in each process are clearly quite different. Each may be affected at more than one step in the uptake and assimilation pathways and involve both short-term and long-term processes, all of which vary from species to species and with environmental conditions. Thus, in this review an empirical approach to quantifying inhibition and preference will be taken which does not require greater understanding of the underlying biochemical mechanisms.

\section{METHODOLOGICAL PROBLEMS IN QUANTIFYING INTERACTIONS BETWEEN AMMONIUM AND NITRATE UPTAKE}

In the following sections the available lab and field data on preference and inhibition will be reviewed. However, there are methodological problems which complicate the interpretation of this data, aside from the already complicated nitrate/ammonium uptake interaction

(1) Preference and inhibition cannot be separated and quantified if controls involving nitrate uptake alone and ammonium uptake alone are not measured. This is difficult and often impossible in the field and rarely done in the lab.

(2) Both preference and inhibition can involve one or more steps in the nitrogen uptake, assimilation, and growth pathways. Depending on the time period over which 'uptake' measurements are made, some assimilation and growth are also measured. How this affects measurements of preference and inhibition in different species and under different conditions is probably quite variable.

(3) Due to problems with calculating nitrogen uptake rates, inhibition may appear to be greatest during simultaneous uptake of nitrate and ammonium (Dortch 1980, Collos 1987, Lund 1987).

(4) Both $V_{\text {max }}$ and $K_{s}$ for uptake are difficult to measure, especially in the field, since the rates of nitrate and ammonium uptake vary with time, and the variation is influenced by nitrogen supply and possibly other environmental variables (reviewed by Collos 1983, Goldman \& Glibert 1983). In addition, there is often a large statistical uncertainty associated with estimates of $K_{s}$.

(5) Regeneration of ammonium (and possibly nitrate?) during incubations to measure nitrogen uptake in 
the field certainly affects ammonium uptake rates (Glibert et al. 1982c) and may also affect the relative rates of nitrate and ammonium uptake.

(6) In the field variations in environmental conditions which affect nitrate and ammonium uptake, but cannot be easily quantified, can mask the effect of ammonium on nitrate uptake.

(7) Both in the lab and the field a variety of methods and protocols have been used for measuring nitrogen uptake which may make comparisons difficult. The data, which will be discussed in the next section, are subject, to different degrees, to these problems, which probably enhances the apparent variability in inhibition/preference, especially in the field where experimental conditions are under less control. Future experiments must minimize these methodological problems in order to quantify the interaction between nitrate and ammonium uptake.

\section{ANALYSIS OF EXISTING DATA ON PREFERENCE}

Preference in the laboratory can best be assessed by comparing $V_{\max }$ or maximum growth rates $\left(\mu_{\max }\right)$ for nitrate alone and ammonium alone (Table 2i Antia et al. 1975). The $V_{\max }$ for ammonium uptake usually exceeds (by up to 11 times) or equals the $V_{\max }$ for nitrate uptake (only 4 exceptions), Despite this marked preference for uptake of ammonium, out of the 70 reports of relative growth rate on nitrate and ammonium (Table 2; Antia et al. 1975), 22 indicate better growth and 30 show the same growth on nitrate compared with ammonium under some, but not necessarily all, environmental conditions. The data for ${ }^{14} \mathrm{C}$ uptake during growth on nitrate and ammonium are too scanty ( 6 species) for comparison with the relative $\mu_{\text {max }}$ although in no case is ${ }^{14} \mathrm{C}$ uptake on nitrate greater than ammonium. If the ${ }^{14} \mathrm{C}$ uptake data are ignored, preference for ammonium is manifested primarily at the Ievel of uptake rather than growth.

It was hypothesized that a low $\mathrm{K}_{\mathrm{s}}$ for nitrate uptake in comparison with ammonium uptake would indicate preference for nitrate. However, in 16 out of 29 measurements the $K_{\mathrm{s}}$ for nitrate exceeds that of ammonium. Not only does this demonstrate again a lack of preference for nitrate, it is contrary to the prediction of Eppley et al. (1969b) that a low $V_{\text {max, }}$ in this case for nitrate (Table 2), would be paired with a low $K_{\mathrm{s}}$. A low $\mathrm{K}_{\mathrm{s}}$ for nitrate may not be required if nitrate is usually supplied sporadically at high concentrations (Dortch et al. 1982). Thus, both the $K_{\mathrm{s}}$ and $V_{\max }$ for nitrate uptake indicate a lack of preference for nitrate uptake.

There are just enough data to compare the relative $u_{\max }$ and $V_{\text {max }}$ for diatoms, dinoflagellates, cyanobacteria, chlorophytes, and others (Table 3). All but one group, the chlorophytes, show a preference for ammonium uptake but not for growth on ammonium. The greatest extremes in this contrast are the diatoms and the 'Other' category, comprised primarily of small flagellates. This is not inconsistent with Malone's (1980) hypothesis that large diatoms would show a preference for growth on nitrate and other studies which show that ammonium may be taken up preferentially by small phytoplankton (Glibert et al. 1982b, Harrison et al. 1983, Nalewajko \& Garside 1983, Probyn 1985, Koike et al. 1986, LeBouteiller 1986, Sahlsten 1987, Harrison \& Wood 1988, Kokkinakis \& Wheeler 1988, Dortch \& Postel 1989a, Dodds et al, unpubl.), although such preference is not always observed (Furnas 1983, Rönner et al. 1983, Probyn \& Painting 1985).

In the field the only indicators of preference which can be examined are the $K_{\mathrm{s}}$ and $V_{\max }$ for uptake (Table 4). Since in the field measurement of uptake of one nitrogen source in the absence of the other is often not possible, these measures of preference are not entirely free of the possible influence of inhibition. However, the results are essentially the same as in the laboratory cultures. The $V_{\text {max }}$ for ammonium uptake exceeds or equals that for nitrate uptake in all cases except for two in upwelling areas. In general the values approach 1 (indicating equal uptake of nitrate and ammonium at saturating concentrations) only in the spring or in upwelling areas, which is consistent with the hypothesis that the large phytoplankton that bloom in those places or times depend mainly on nitrate (Malone 1980). As in the lab, the $K_{\mathrm{s}}$ values for nitrate generally exceed or equal those for ammonium, indicating little preference for ammonium.

The 'Comments' in Tables 2 and 4, and other data which could not be easily categorized in the tables, show that preference can be modified considerably by environmental conditions. Nitrogen deficiency elevates the $V_{\max }$ for ammonium uptake (reviewed in Collos 1983, Goldman \& Glibert 1983). The effect on $V_{\max }$ for nitrate is quite variable (Dortch et al. 1982, Collos 1983, Parslow et al. 1984) but in general there is at most a small increase and, often, a decrease. Thus, nitrogen deficiency may dramatically increase the preference for ammonium. Further, when ambient nitrogen is depleted, small phytoplankton often predominate, which, as mentioned above, may prefer ammonium.

Since nitrate reduction can take up to one third of photosynthetically produced reducing power (Losada \& Guerrero 1979, Syrett 1981), it can be postulated that preference for ammonium would be greater at low light. Certainly, ammonium uptake appears to be less Jight-dependent than nitrate uptake, with higher dark uptake rates and less variation with light intensity (Goering et al. 1964. Caperon \& Ziemann 1976, Cloern 1977, Kuenzler et al. 1979. Nelson \& Conway 1979, Murphy 1980, Olson 1980, Nalewajko \& Garside 1983, 


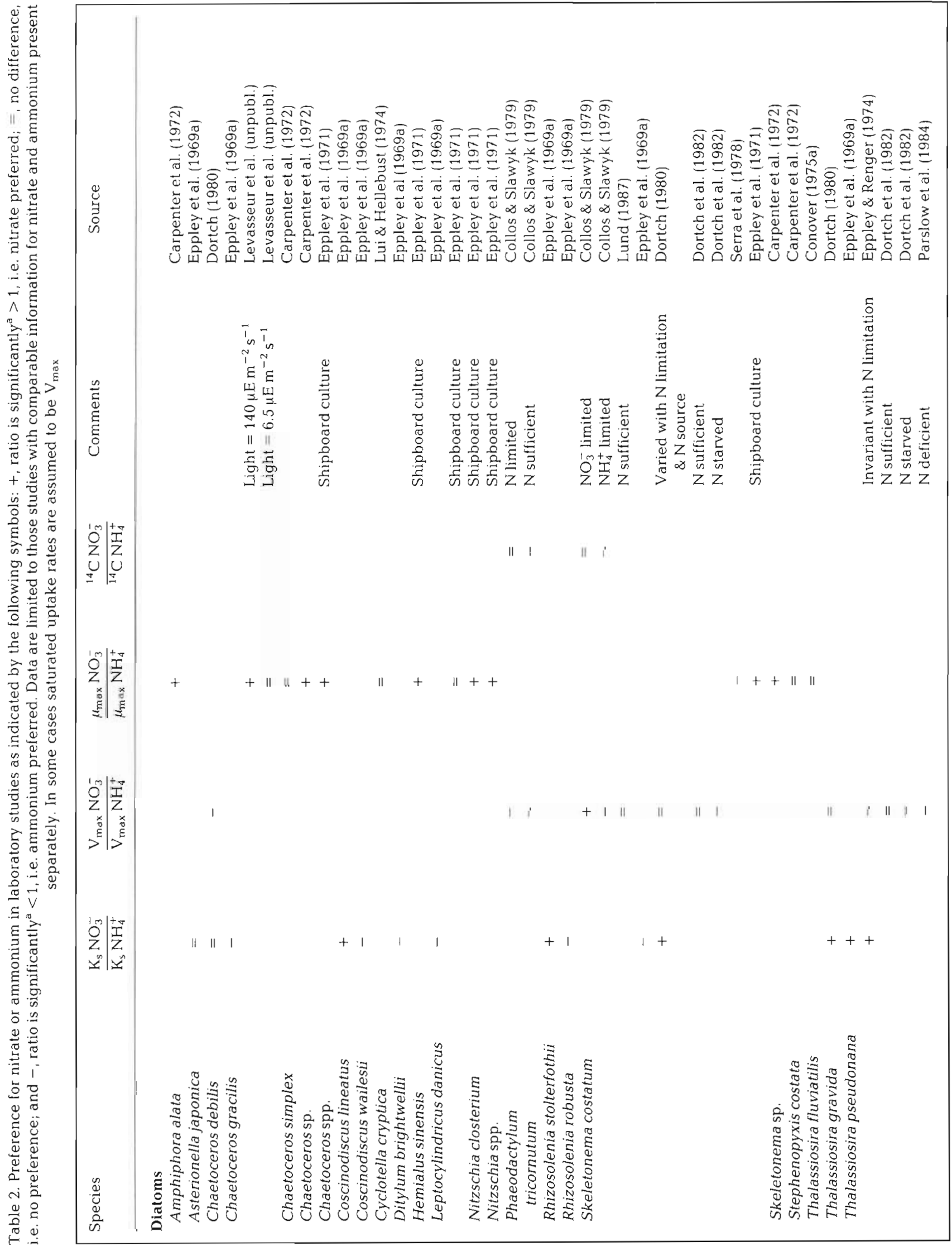




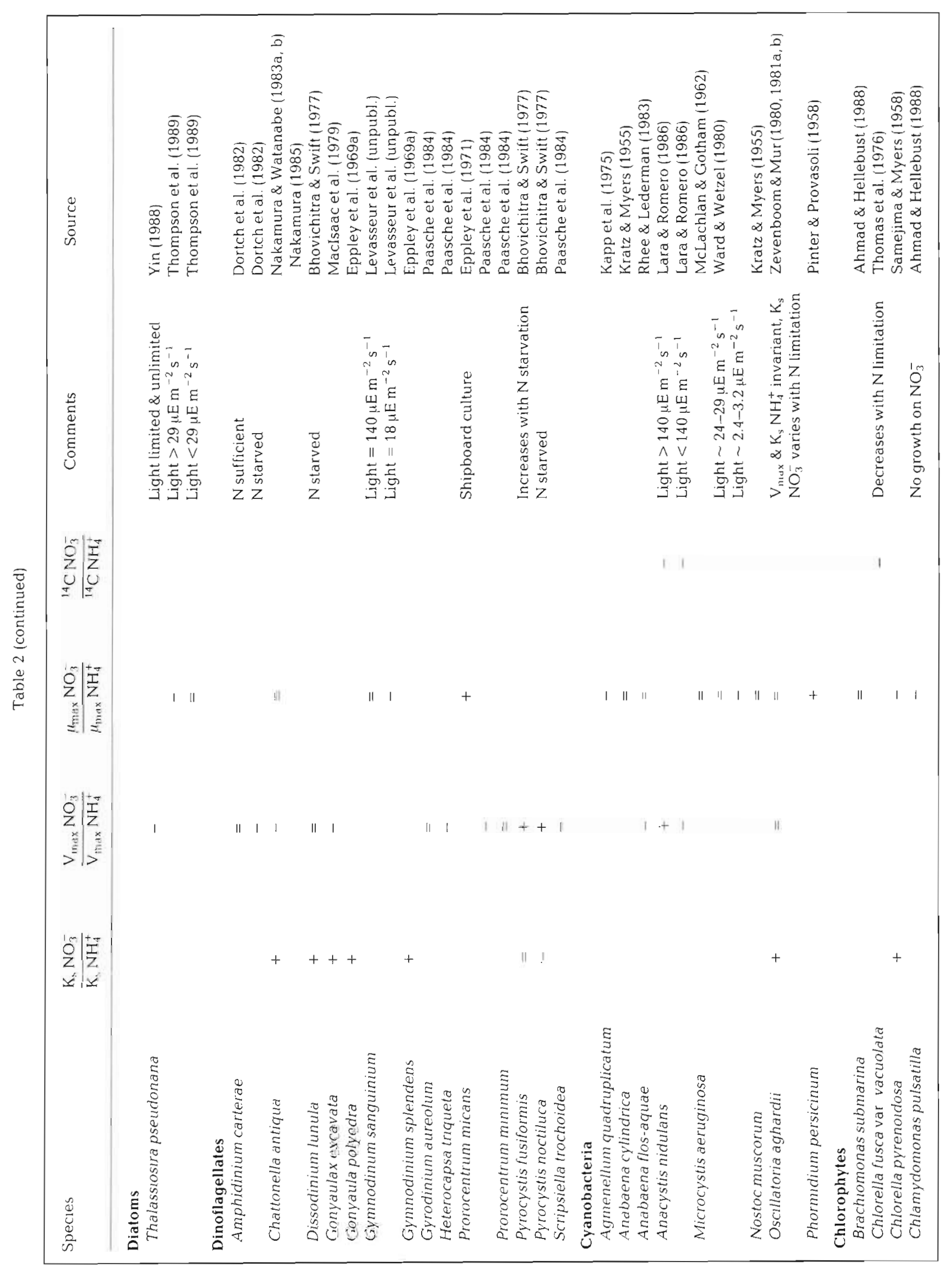




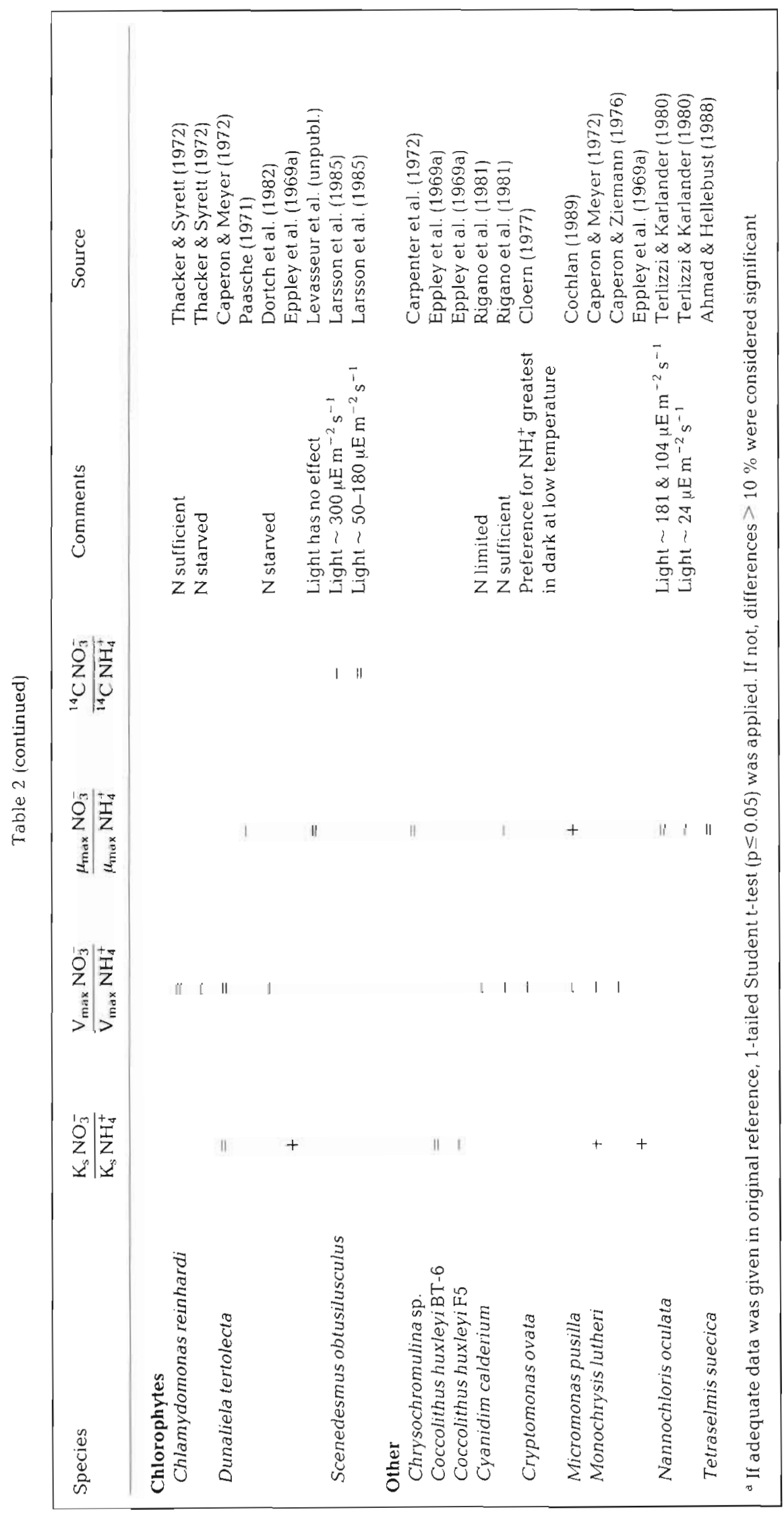


Table 3. Percent of reports ${ }^{\mathrm{a}}$ of species preference for ammonium $^{\mathrm{b}}$ compiled from Table 2 and Antia ot al. (1975)

\begin{tabular}{|c|c|c|}
\hline \multirow[t]{2}{*}{ Taxon } & \multicolumn{2}{|c|}{$\%$ Preference $\mathrm{NH}_{4}^{+}$} \\
\hline & $\mathrm{V}_{\max }$ & $\mu_{\max }$ \\
\hline Diatoms & 65 (17) & $16 \quad(25)$ \\
\hline Dinoflagellates & $45(11)$ & $20 \quad(5)$ \\
\hline Cyanobacteria & $50 \quad(4)$ & $28(14)$ \\
\hline Chlorophytes & $50 \quad(4)$ & 57 (7) \\
\hline Other & $100 \quad(6)$ & 26 (19) \\
\hline \multicolumn{3}{|c|}{$\begin{array}{l}\text { "Number of reports given in parentheses. Duplicates or } \\
\text { conflicting reports for the same species counted seperately } \\
\text { since environmental conditions can influence preference } \\
\text { b Preference defined as in Table } 2\end{array}$} \\
\hline
\end{tabular}

Paasche et al. 1984, Whalen \& Alexander 1984, Kanda et al. 1985, Koike et al. 1986, Fisher et al. 1988), although, again there are exceptions (Garside 1981. Glibert et al, 1982a, Collos \& Slawyk 1986, McCarthy \& Nevins 1986, Sahlsten 1987). For the few studies in which preference can be assessed directly at different light levels (Table 2), 5 species show increased preference for ammonium at low light, one no difference, and one less preference. However, one other species, Thalassiosira pseudonana, showed greater preference for ammonium at low light when maximum uptake rates (Yin 1988) were compared but decreased preference for ammonium at low light when growth rates were considered (Thompson et al. 1989). Since preference for ammonium may be generally more evident with uptake than growth, care must be taken in assessing the effect of light on preference until there is more data for relative $V_{\max }$ at different light levels.

Temperature can also affect the relative rates of nitrate and ammonium uptake, but there is no consensus about which is more temperature-dependent Cloern 1977, Kuenzler et al. 1979, Olson 1980, Tischner 1981, Glibert et al. 1982b, Whalen \& Alexander 1984, Kanda et al. 1985).

In summary, preference for ammonium is manifested primarily in a higher $V_{\max }$ and a lower $K_{s}$ for ammonium uptake than nitrate uptake. Preference for ammonium uptake is not universal, and is least likely in the spring in temperate regions or in upwelling areas when large diatoms are thought to dominate. Furthermore, the most common environmental stresses encountered by phytoplankton, low light or low nitrogen availability may increase the preference for ammonium uptake. Despite the preference for ammonium uptake, growth on nitrate is ofter as good or better than that on ammonium. Finally, there is considerable species variation in all aspects of preference.

\section{ANALYSIS OF EXISTING DATA ON INHIBITION}

The inhibition of nitrate uptake by ammonium is a highly variable process. In laboratory cultures it ranges from no inhibition to complete inhibition and depends on the species and environmental conditions (Table 5). In general, inhibition varies with the degree of nitrogen deficiency (Caperon \& Meyer 1972, Eppley \& Renger 1974, Bienfang 1975. Conway 1977. Tischner 1981, Terry 1982), although Dunaliela tertiolecta (Caperon \& Meyer 1972) and Skeletonema costatum (Dortch \& Conway 1984) are exceptions. The nitrogen source used for growth prior to exposure to both nitrate and ammonium may predispose phytoplankton to different degrees of inhibition (Dortch \& Conway 1984, Dortch et al. unpubl.). Finally, low light or darkness may increase the likelihood of inhibition (Bates 1976, Ohmori et al. 1977), as would be expected from the earlier discussion of the effect of light on preference. However, in Thalassiosira pseudonana ammonium stimulates nitrate uptake in low light (Yin 1988). There are no data on the variation of inhibition with temperature or size of phytoplankter. Because of the variability in the results in Table 5, probably due to the many differences in experimental design and conditions, it is not possible to infer a pattern to the degree of inhibition for algal species, either by size, taxonomic grouping, or location where isolated.

There are very few field studies in which inhibition is separated from preference, because of the need to compare the nitrate uptake rates with and without added ammonium (if ambient ammonium is high, no suitable control is possible). Again it is apparent that inhibition (Table 1) is quite variable but almost never complete. Further, the degree of inhibition is much less than would be expected from the f-ratio ( $\mathrm{NO}_{3}^{-}$uptake/ total $\mathrm{N}$ uptake), which combines both inhibition and preference.

The threshold for the effect of ammonium on nitrate uptake is quite variable, ranging in cultures from 0.1 to $90 \mu \mathrm{M}$ (Table 5), and in the field from 0.1 to $15 \mu \mathrm{M}$ (Kuenzler et al. 1979, Toetz 1981, Paasche \& Kristiansen 1982, Berman et al. 1984, Priscu \& Priscu 1984, Probyn 1985, Lipschultz et al. 1986, Quéguiner et al. 1986, Pennock 1987). Considerable variation would be expected in thresholds because they probably result from a number of interacting biochemical processes (but the cause is currently unknown) and they are defined differently in various studies. Regardless, nitrate uptake is rarely zero, and is often substantial, even when the threshold is reached.

Much has been written about the biochemical mechanism of ammonium inhibition of nitrate uptake. Separating preference from inhibition is a first step in clarifying the mechanism. It is also simplified by con- 


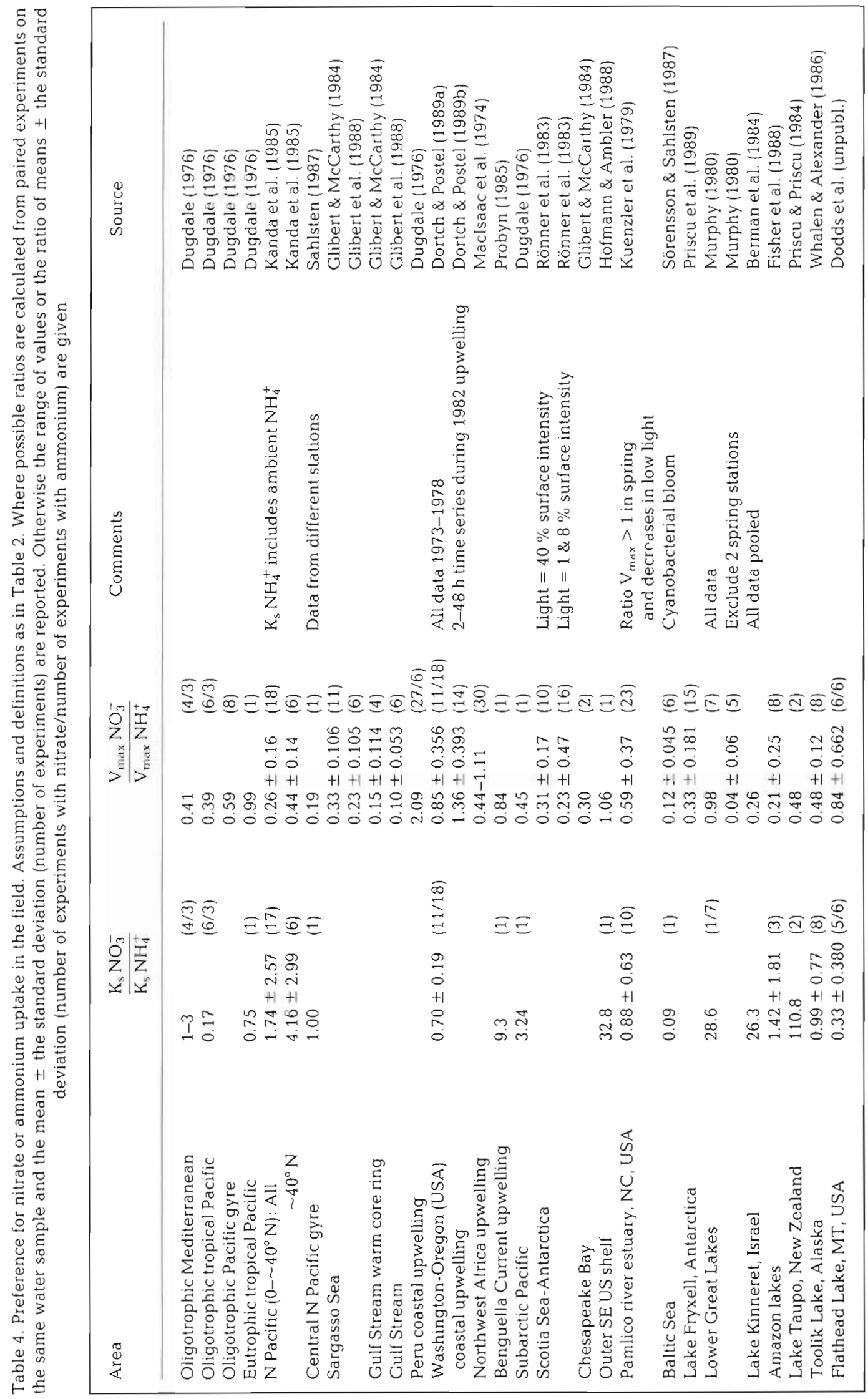




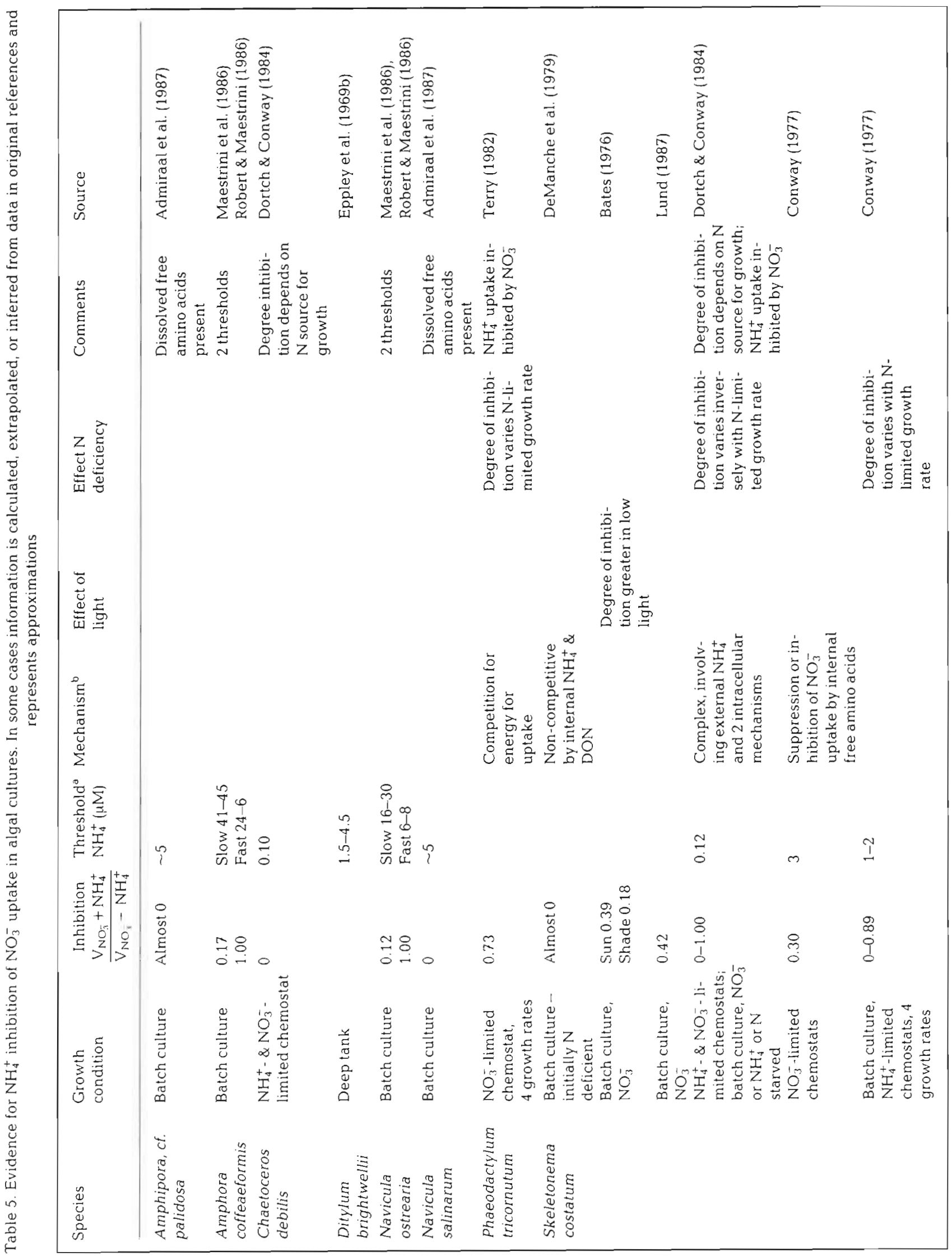




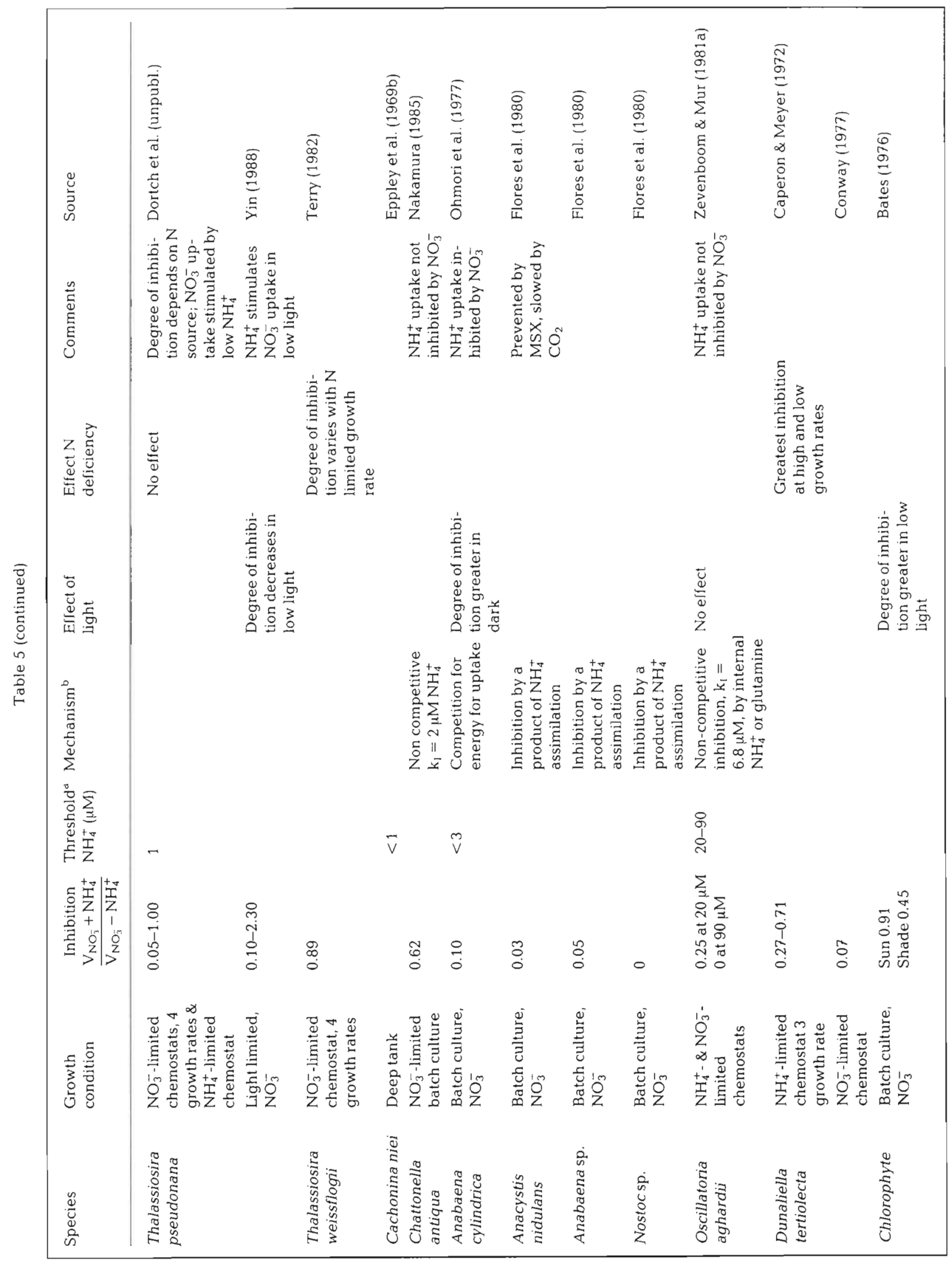




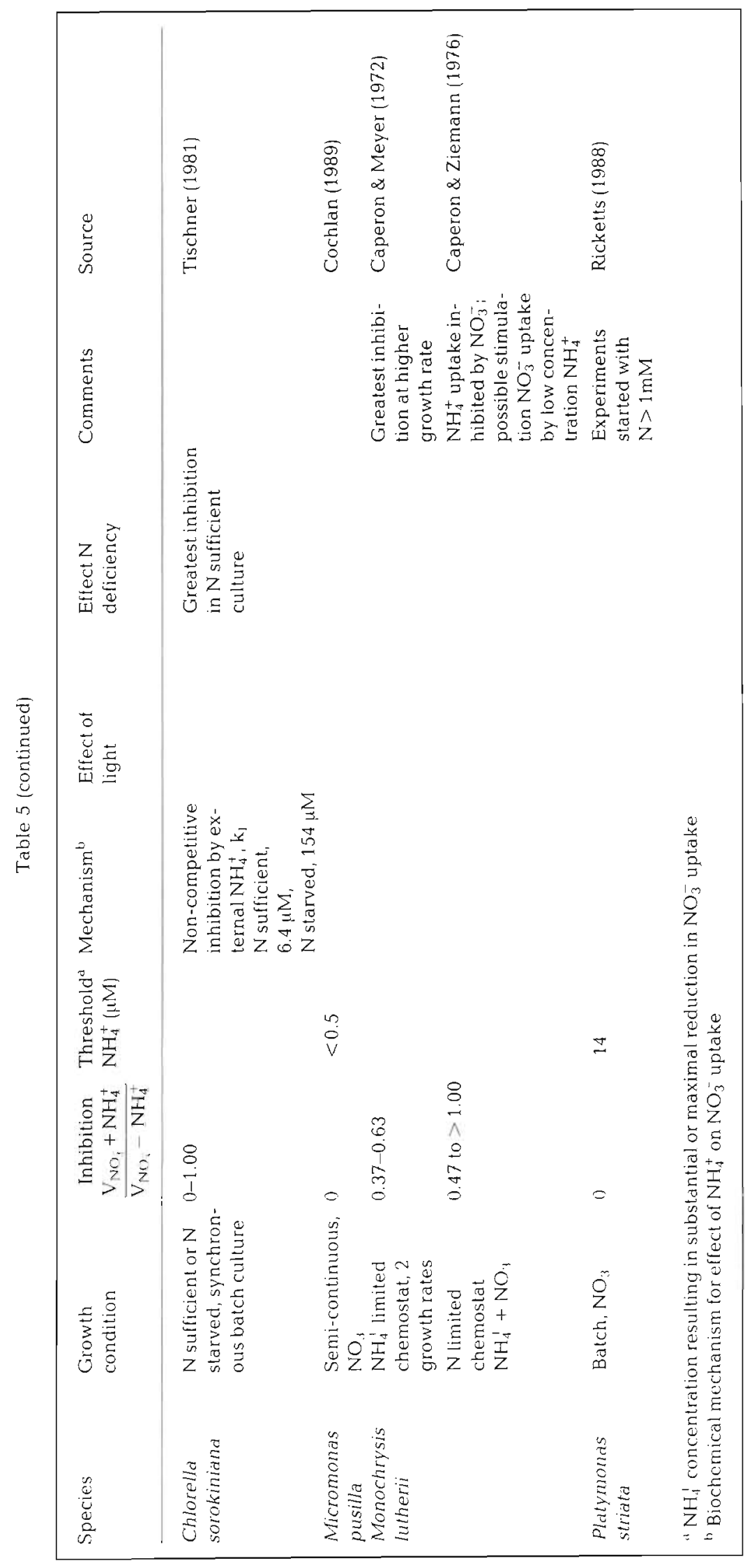


sidering the regulation of uptake separately from assimilation. Even so, it is possible to hypothesize a number of mechanisms (Table 5). This is not just an academic question for several reasons. The mechanism of inhibition may dictate how inhibition is affected by environmental conditions. For example, if nitrate and ammonium uptake compete for energy for transport across the cell membrane (Ohmori et al. 1977, Terry 1982), then inhibition should be greatest in low light or in the dark. As a second example, if external ammonium is a competitive inhibitor of nitrate uptake, the inhibition should be overcome by increasing the nitrate concentration, but if ammonium is a non-competitive inhibitor, then no amount of nitrate will decrease the inhibition. As mentioned in a previous section, the $\mathrm{RPI}_{\mathrm{NO}}$ - may be highest when phytoplankton are nitrogen-limited and concentrations of all forms of nitrogen are low (McCarthy et al. 1977, Paasche \& Kristiansen 1982, Furnas 1983, Glibert \& McCarthy 1984, Cochlan 1986, Whalen \& Alexander 1986, Probyn 1988 ) or when nitrate concentrations are very high (Carpenter \& Dunham 1985, Harrison et al. 1987, Pennock 1987, Collos et al. 1989, Dortch \& Postel 1989a). While part of the discrepancy may be due to variations in both preference and inhibition, knowledge of the mechanism of inhibition might help explain the differences.

The mechanism will also dictate how nitrate uptake can be described in a model. Current models fall into several distinct categories: (1) a linear relationship between nitrate uptake and ammonium concentration; (2) a linear relationship between nitrate uptake and nitrate and ammonium concentrations, which implies competitive inhibition (Harrison et al. 1987, Collos 1989); (3) a non-linear relationship between nitrate uptake and ammonium concentration based on noncompetitive inhibition (Zevenboom \& Mur 1981a, Nakamura 1985) or derived empirically (Hofmann \& Ambler 1988, Dodds et al. unpubl.). In order to compile the data in Table 1, all the data from each study cited were plotted as a function of ammonium concentration. Ideally, the data could have been fit by one of these approaches and the $f$-ratio, ratio of nitrate uptake/ ammonium uptake, or inhibition calculated at $1 \mu \mathrm{M}$ ammonium. In practice, even if the data could be fit with one of the equations, the fit was generally poor because at high ammonium concentrations $(>1 \mu \mathrm{M})$ there are very few data points. At low ammonium concentrations, while some nitrate uptake rates are high, most are quite low, implying that other factors besides external ammonium are influencing the interaction between ammonium and nitrate uptake. For example, none of these models can account for changes in uptake which occur in response to environmental conditions nor do they allow for regulation by intracellular mechanisms (Table 5) as well as external ammonium. With the renewed interest in using nitrate uptake as a measure of new production and carbon flux out of the euphotic zone, there is an increased need to be able to model nitrate uptake in a way that realistically reflects the natural environment. This will only be accomplished when the inhibitory mechanism is better understood.

The inhibitory interaction between nitrate and ammonium uptake is complicated by 2 other processes. Besides ammonium inhibition of nitrate uptake, there are also reports that nitrate inhibits ammonium uptake, although to a lesser degree (Caperon \& Ziemann 1976 , Ohmori et al. 1977, Terry 1982, Dortch \& Conway 1984, Yin 1988). Others have not observed such inhibition, although they deliberately looked for it (Kuenzler et al. 1979, Zevenboom \& Mur 1981a, Nakamura 1985, Lund 1987, Dortch et al. unpubl.). Secondly, it appears that the presence of, usually, small amounts of ammonium may stimulate nitrate uptake, even though larger amounts inhibit (Conover 1975b, Caperon \& Ziemann 1976, Glibert et al. 1982b, Yin 1988, Dortch et al. unpubl.). Neither process fits the current view of the interaction between nitrate and ammonium uptake.

\section{CONCLUSION}

In summary, the presence of ammonium does not reduce nitrate uptake to the degree which is generally believed. The apparent negative effect of ammonium on nitrate uptake can be divided into 2 quite distinct processes, preference for ammonium and inhibition of nitrate uptake by ammonium. Some of what has been called 'inhibition' in the past is really the indirect result of preference for ammonium, manifested primarily in a higher $V_{\max }$ and a lower $\mathrm{K}_{\mathrm{s}}$ for ammonium uptake than nitrate uptake. Inhibition, resulting from the direct effect of ammonium on nitrate uptake, does occur, but is generally much less extreme and more variable a phenomenon than has been generally appreciated. There is considerable variation between species in both inhibition and preference to which there is at present no apparent pattern. Furthermore, both are strongly influenced by environmental conditions. It can be hypothesized from the available data that preference for ammonium will be maximal with low light and nitrogen deficiency, whereas inhibition will be maximal with nitrogen sufficiency and low light. However, it is already apparent that some species are exceptions to these generalizations. Finally, it is difficult to incorporate the possibilities that ammonium stimulates nitrate uptake or that nitrate inhibits ammonium uptake within the framework of the current paradigm.

Although the interaction between nitrate and 
ammonium uptake has been studied at length, a fundamental understanding of the interaction is still lacking. The review suggests 2 areas where future research may be most useful:

(1) Experiments to determine the specific biochemical mechanisms involved in preference and inhibition and

(2) More studies of the variation in preference and inhibition with species and environmental conditions.

Two methodological recommendations can also be made.

(1) Much of the experimental work on biochemical mechanisms has utilized freshwater, green algal or cyanobacterial weed species whose nitrogen utilization may be quite different from most phytoplankton. A wider variety of more representative species should be utilized for these kinds of studies.

(2) In order to at least separate preference and inhibition and to make it possible to observe nitrate inhibition of ammonium uptake and stimulation of nitrate by ammonium, appropriate controls (nitrate uptake alone and ammonium uptake alone) and ammonium uptake as a function of nitrate concentration must also be measured, both in the laboratory and the field.

With these recommendations in mind and an appreciation for the complexity of the interaction between nitrate and ammonium uptake, it should be possible to design experiments which will lead to an understanding of the underlying biochemical mechanisms and thus, to a new paradigm to describe the interaction. This in turn will make it possible to interpret measurements of nitrate uptake in the field and model the relationship of nitrate uptake to productivity and phytoplankton processes in the ocean.

Acknowledgements. This research was supported by NSF grant OCE 82-19746. I thank William P. Cochlan, Yves Collos, Walter K. Dodds, Paul J. Harrison, E. Paasche, and T E. Whitledge for comments on an initial draft and for many additional references, and William P. Cochlan, Walter K. Dodds, Maurice E. Levasseur, and Peter A. Thompson for allowing me to include previously unpublished data.

\section{LITERATURE CITED}

Admiraal, W., Riaux-Gobin, C., Laane, R. W. P. M. (1987). Interactions of ammonium, nitrate, and $\mathrm{D}$ - and L-amino acids in the nitrogen assimilation of two species of estuarine benthic diatoms. Mar Ecol. Prog. Ser 40:267273

Ahmad, I., Hellebust, J. A. (1988). Enzymology of ammonium assimilation in three green flagellates. New Phytol, 109:4 15-421

Antia, N. J., Berland, B. R., Bonin, D. J., Maestrini, S. Y (1975). Comparative evaluation of certain organic and inorganic sources of nitrogen for phototrophic growth of marme microalgae. J. mar. biol. Ass. U. K. 55:519-539

Bates, S. S. (1976). Effects of light and ammonium on nitrate uptake by two species of estuarine phytoplankton. Limnol. Oceanogr 21:212-218

Berman, T., Sherr, B. F., Sherr, E., Wynne, D., McCarthy, J. J. (1984). The characteristics of ammonium and nitrate uptake by phytoplankton in Lake Kinneret. Limnol. Oceanogr. 29:287-297

Bhovichitra, M., Swift, E. (1977). Light and dark uptake of nitrite and ammonium by large oceanic dinoflagellates: Pyrocystis noctiluca, Pyrocystis fusiformis, Dissodinium Iunuli. Limnol. Oceanogr. 22:73-83

Bienfang, P. K. (1975). Steady-state analysis of nitrateammonium assimilation by phytoplankton. Limnol. Oceanogr. 20:402-411

Blasco, D., Conway, H. L. (1982). Effect of ammonium on the regulation of nitrate assimilation in natural phytoplankton. populations. J. exp. mar. Biol. Ecol 61:157-168

Caperon, J., Meyer, J. (1972). Nitrogen-limited growth of phytoplankton. II. Uptake kinetics and their role in nutrient limited growth of phytoplankton. Deep Sea Res. 19:619-632

Caperon, J., Ziemann, D. A. (1976). Synergistic effects of nitrate and ammonium ion on the growth and uptake kinetics of Monochrysis lutheri in continuous culture. Mar. Biol. 36:73-84

Carpenter, E. J, Dunham, S. (1985). Nitrogenous nutrient uptake, primary production and species composition of phytoplankton in the Carmans River estuary, Long Island, N. Y. Limnol. Oceanogr. 30:513-526

Carpenter, E. J., Remsen, C. C., Watson, S. W. (1972). Utilization of urea by some marine phytoplankters. Limnol. Oceanogr. 17:265-269

Cloern, J. E. (1977). Effects of light intensity and temperature on Cryptomonas ovata (Cryptophyceae) growth and nutrient uptake rates. J. Phycol. 13:389-395

Cochlan, W. P. (1986). Seasonal study of uptake and regeneration of nitrogen on the Scotian shelf. Cont. Shelf Res. $5: 555-577$

Cochlan, W. P. (1989). Nitrogen uptake by marine phytoplankton: the effects of irradiance, nitrogen supply, and diel periodicity. Ph. D. thesis, Department of Oceanography, University of British Columbia Vancouver

Collos, Y (1982). Transient situations in nitrate assimilation by marine diatoms. 3 . Short-term uncoupling of nitrate uptake and reduction. J. exp. mar. Biol. Ecol. 62:285-295

Collos, Y (1983). Transient situations in nitrate assimilation by marine diatoms. 4. Non-linear phenomena and the estimation of the maximum uptake rate. J. Plankton Res. 5:677691

Collns, $\mathrm{Y}$ (1987). Calculations of ${ }^{15} \mathrm{~N}$ uptake rates by phytoplankton assimilating one or several nitrogen sources. Appl. Radiat. Isot. 38:275-282

Collos, Y (1989). A linear model of external interactions during uptake of different forms of inorganic nitrogen by microalgae. J. Plankton Res. 11.521-533

Collos, Y., Maestrini, S. Y., Robert, J. M. (1989). Long-term nitrate uptake by oyster-pond microalgae in presence of high ammonium concentrations. Limnol. Oceanogr. 34:959-966

Collos, Y., Slawyk, G. (1979). ${ }^{13} \mathrm{C}$ and ${ }^{15} \mathrm{~N}$ uptake by marine phytoplankton. I. Influence of nitrogen source and concentration in laboratory cultures of diatoms. J. Phycol. 15:186190

Collos, Y., Slawyk, G. (1986). ${ }^{13} \mathrm{C}$ and ${ }^{15} \mathrm{~N}$ uptake by marine phytoplankton. IV Uptake ratios and the contrbution of 
nitrate to the productivity of Antarctic waters (Indian Ocean sector). Deep Sea Res. 33:1039-1051

Conover, S. A. M. (1975a). Partitioning of nitrogen and carbon in cultures of the marine diatom Thalassiosira fluviatilis supplied with nitrate, ammonium, or urea. Mar. Biol. $32: 231-246$

Conover, S. A. M. (1975b). Nitrogen utilization during spring blooms of marine phytoplankton in Bedford Basin, Nova Scotia, Canada. Mar. Biol. 32:247-262

Conway, H. L. (1977). Interaction of inorganic nitrogen in the uptake and assimilation by marine phytoplankton. Mar. Biol. 39:221-232

DeManche, J. M., Curl, Jr, H. C., Lundy, D. W., Donaghay, P. L. (1979). The rapid response of the marine diatom Skeletonema costatum to changes in external and internal nutrient concentration. Mar. Biol. 53:323-333

Dortch, Q. (1980). Nitrate and ammonium assimilation in three marine diatoms. Ph.D. dissertation, University of Washington, Seattle

Dortch, Q., Ahmed, S. I., Packard, T. T. (1979). Nitrate reductase and glutamate dehydrogenase activities in Skeletonema costatum as measures of nitrogen assimilation rates. J. Plankton Res. 1:169-186

Dortch, Q., Clayton, Jr, J. R., Thoresen, S. S., Bressler, S. L. Ahmed, S. I. (1982). Response of marine phytoplankton to nitrogen deficiency: decreased nitrate uptake vs enhanced ammonium uptake. Mar Biol. 70:13-19

Dortch, Q., Conway, H. L. (1984). Interaction between nitrate and ammonium uptake: variation with growth rate, nitrogen source, and species. Mar Biol. 79:151-164

Dortch, Q., Postel, J. R. (1989a). Phytoplankton-nitrogen interactions. In: Landry, M. R., Hickey, B. M. (eds.) Coastal oceanography of Washington and Oregon. Elsevier Science, Amsterdam, p. 139-173

Dortch, Q., Postel, J. R. (1989b). Biochemical indicators of N utilization by phytoplankton during upwelling off the Washington coast. Limnol. Oceanogr. 34:758-773

Dugdale, R. C. (1976). Nutrient cycles. In: Cushing, D. H., Walsh, J. J. (eds.) The ecology of the sea. Blackwell's Scientific Publications, Oxford, p. 141-172

Eppley, R. W., Carlucci, A. F., Holm-Hansen, O., Kiefer, D. McCarthy, J. J., Venrick, E., Williams, P. M. (1971). Phytoplankton growth and composition in shipboard cultures supplied with nitrate, ammonium, or urea as the nitrogen source. Limnol. Oceanogr. 16:741-751

Eppley, R. W., Coatsworth, J. L., Soloranzo, L. (1969a). Studies of nitrate reductase in marine phytoplankton. Limnol. Oceanogr. 14:194-205

Eppley, R. W., Peterson, B. J. (1979). Particulate organic matter flux and planktonic new production in the deep ocean. Nature, Lond. 282:677-680

Eppley, R. W., Renger, E. H. (1974). Nitrogen assimilation of an oceanic diatom in nitrogen-limited continuous culture. J. Phycol. 10:15-23

Eppley, R. W., Renger, E. H., Harrison, W. G., Cullen, J. J. (1979). Ammonium distribution in southern California coastal waters and its role in the growth of phytoplankton. Limnol. Oceanogr, 24:495-509

Eppley, R. W., Rogers, J. N., McCarthy, J. J. (1969b). Halfsaturation constants for uptake of nitrate and ammonium by marine phytoplankton. Limnol. Oceanogr. 14:912-919

Fisher, T. R., Morrissey, K. M., Carlton, P. R., Alves, L. F., Melack, J. M. (1988). Nitrate and ammonium uptake by plankton in an Amazon River flood plain lake. J. Plankton Res. 10:7-29

Flores, E., Guerrero, M. G., Losada, M. (1980). Short-term ammonium inhibition of nitrate utilization by Anacystis nidulans and other cyanobacteria. Arch. Microbiol. 128:137-144

Furnas, M. J. (1983). Nitrogen dynamics in lower Narraganset Bay, Rhode Island. I. Uptake by size-fractionated phytoplankton populations. J. Plankton Res. 5:657-676

Garside, C. (1981). Nitrate and ammonium uptake in the apex of the New York Bight. Limnol. Oceanogr 26:731-739

Glibert, P. M., Biggs, D. C., McCarthy, J. J. (1982a). Utilization of ammonium and nitrate during austral summer in the Scotia Sea. Deep Sea Res. 29:837-850

Glibert, P. M., Dennett, M.R., Caron, D. A. (1988). Nitrogen uptake and $\mathrm{NH}_{4}+$ regeneration by pelagic microplankton and marine snow from the North Atlantic. J. mar. Res. $46: 837-852$

Glibert, P. M., Goldman, J. C., Carpenter, E. J. (1982b). Seasonal variations in the utilization of ammonium and nitrate by phytoplankton in Vineyard Sound, Massachusetts, U.S.A. Mar. Biol. 70:237-250

Glibert, P. M., Lipschultz, F., McCarthy, J. J., Altabet, M. A. (1982c). Isotope dilution models of uptake and remineralization of ammonium by marine plankton. Limnol. Oceanogr 27:639-650

Glibert, P. M., McCarthy, J. J. (1984). Uptake and assimilation of ammonium and nitrate by phytoplankton: indices of nutritional status for natural assemblages. J. Plankton Res. $6: 677-697$

Goering, J. J., Dugdale, R. C., Menzel, D. W. (1964). Cyclic diurnal variations in the uptake of ammonium and nitrate by photosynthetic organisms in the Sargasso Sea. Limnol. Oceanogr. 9:448-451

Goering, J. J., Wallen, D. D., Naumann, R. A. (1970). Nitrogen uptake by phytoplankton in the discontinuity layer of the eastern subtropical Pacific Ocean. Limnol. Oceanogr. $15: 789-796$

Goldman, J. C., Glibert, P. M. (1983). Kinetics of inorganic nitrogen uptake by phytoplankton. In: Carpenter, E. J., Capone, D. G. (eds.) Nitrogen in the marine environment, Academic Press, New York, p. 233-274

Harrison, W. G., Douglas, D., Falkowski, P., Rowe, G., Vidal, J. (1983). Summer nutrient dynamics of the Middle Atlantic Bight: nitrogen uptake and regeneration. J. Plankton Res. 5:539-556

Harrison, W. G., Head, E. H. H., Conover, R. J., Longhurst, A. R., Sameoto, D. D. (1985). The distribution and metabolism of urea in the eastern Canadian Arctic. Deep Sea Res. 32:23-42

Harrison, W. G., Platt, T. Irwin, B. (1982). Primary production and nutrient assimilation by natural phytoplankton populations of the Eastern Canadian Arctic. Can. J. Fish. Aquat. Sci. 39:335-345

Harrison, W. G., Platt, T., Lewis, M. R. (1987). f-ratio and its relationship to ambient nitrate concentration in coastal waters. J. Plankton Res. 9:235-248

Harrison, W. G., Wood, L. J. E. (1988). Inorganic nitrogen uptake by marine picoplankton: evidence for size partitioning. Limnol. Oceanogr. 33:468-475

Harvey, W. A., Caperon, J. (1976). The rate of utilization of urea, ammonium, and nitrate by natural populations of marine phytoplankton in a eutrophic environment. Pacif. Sci. 30:329-340

Hofmann, E. E., Ambler, J. W. (1988). Plankton dynamics on the outer southeastern U. S. continental shelf: Part II. A time-dependent biological model. J. mar. Res. 46:883-917

Kanda, J., Saino, T., Hattori, A. (1985). Nitrogen uptake by natural populations of phytoplankton and primary production in the Pacific Ocean: regional uptake capacity, Limnol. Oceanogr. 30:987-999 
Kapp, R., Stevens, S. E., Fox, J. L. (1975). A survey of available nitrogen sources for the growth of the blue-green alga, Agmenellum quadriplicatum. Arch. Microbiol. 104:135-138

Koike, I., Holm-Hansen, O., Biggs, D. C. (1986). Inorganic nitrogen metabolism by Antarctic phytoplankton with special reference to ammonia cycling. Mar Ecol. Prog. Ser 30:105-116

Kokkinakis, S. A., Wheeler, P. A. (1987). Nitrogen uptake and phytoplankton growth in coastal upwelling regions. Limnol. Oceanogr. 32:1112-1123

Kokkinakis, S. A., Wheeler, P. A. (1988). Uptake of ammonium and urea in the northeast Pacific: comparison between netplankton and nanoplankton. Mar. Ecol. Prog. Ser. 43:113-124

Kratz, W. A., Myers, J. (1955). Nutrition and growth of several blue-green algae. Am. J. Bot. 42:282-287

Kristiansen, S., Lund, B. Aa. (1989). Nitrogen cycling in the Barents Sea I. Uptake of nitrogen in the water column. Deep Sea Res. 36:255-268

Kuenzler, E. J., Stanley, D. W., Koenings, J. P. (1979). Nutrient kinetics of phytoplankton in the Pamlico River, North Carolina. Water Resources Research Institute of the University of North Carolina, Project No. B-092-NC

Lara, C., Romero, J. M. (1986). Distinctive light and $\mathrm{CO}_{2}^{-}$ fixation requirements of nitrate and ammonium utilization by the cyanobacterium Anacystis nidulans. Plant Physiol. $81: 686-688$

La Roche, J. (1983). Ammonium regeneration: its contribution to phytoplankton nitrogen requirements in a eutrophic environment. Mar Biol. 75:231-240

Larsson, M., Olsson, T., Larsson, C. -M. (1985). Distribution of reducing power between photosynthetic carbon and nitrogen assimilation in Scenedesmus. Planta 164:246-253

LeBouteiller, A. (1986). Environmental control of nitrate and ammonium uptake by phytoplankton in the equatorial Atlantic Ocean. Mar. Ecol. Prog. Ser. 30:167-179

Lipschultz, F., Wofsey, S. C., Fox, L. E. (1986). Nitrogen metabolism of the eutrophic Delaware River ecosystem. Limnol. Oceanogr 31:701-716

Losada, M., Guerrero, M. G. (1979). The photosynthetic reduction of nitrate and its regulation. In: Barber, J. (ed.) Photosynthesis in relation to model systems. Elsevier/NorthHolland Biomedical Press, Amsterdam, p. 363-408

Lui, M. S., Hellebust, J. A. (1974). Uptake of amino acids by the marine centric diatom Cyclotella crytpica. Can. J. Microbiol. 20(8): 1109-1118

Lund, B. A. (1987). Mutual interference of ammonium, nitrate, and urea on uptake of ${ }^{15} \mathrm{~N}$ sources by the marine diatom Skeletonema costatum. J. exp. mar. Biol. Ecol. 113:167-180

Macisaac, J. J., Dugdale, R. C. (1972). Interactions of light and inorganic nitrogen in controlling nitrogen uptake in the sea. Deep Sea Res. 19:209-232

Maclsaac, J. J., Dugdale, R. C., Slawyk, G. (1974). Nitrogen uptake in the northwest Africa upwelling area: results from the Cineca-Charcot II cruise. Tethys 6:67-76

Macisaac, J. J., Grunseich, G. S., Glover, H. E., Yentsch, C. M. (1979). Light and nutrient limitation in Gonyaulax excavata: nitrogen and carbon trace results. In: Taylor, D. L., Seliger, K. (eds.) Toxic dinoflagellate blooms. Elsevier/ North Holland, Amsterdam, p. 107-110

Maestrini, S. Y. Robert, J. -M., Leftley, J. W., Collos, Y. (1986). Ammonium thresholds for simultaneous uptake of ammonium and nitrate by oyster-pond algae. J. exp. mar. Biol. Ecol. 102:75-98

Malone, T C. (1980). Algal size. In: Morris, I. (ed.) The physiological ecology of phytoplankton. Blackwell, London, p. 433-464
McCarthy, J. J, Nevins, J. L. (1986). Utilization of nitrogen and phosphorus by primary producers in warm-core ring 82-B following deep convective mixing. Deep Sea Res. 33:1773-1788

MCCarthy, J. J., Taylor, R. W., Taft, J. L. (1977), Nitrogenous nutrition of the plankton in the Chesapeake Bay. 1. Nutrient availability and phytoplankton preferences. Limnol. Oceanogr. 22:996-1011

McCarthy, J. J., Wynne, D., Berman, T (1982). The uptake of dissolved nitrogenous nutrients by Lake Kinneret (Israel) microplankton. Limnol. Oceanogr. 27:673-680

McLachlan, J., Gotham, P. R. (1962). Effects of pH and nitrogen sources on growth of Microcystis aeruginosa Kütz. Can. J. Microbiol. 8:1-11

Morris, I. (1974). Nitrogen assimilation and protein synthesis. In: Stewart, W. D. P. (ed.) Algal physiology and biochemistry. University of California Press, Berkeley and Los Angeles, p. 583-609

Murphy, T P. (1980). Ammonia and nitrate uptake in the lower Great Lakes. Can. J Fish. Aquat. Sci. 37:1365-1372

Nakamura, Y (1985). Ammonium uptake kinetics and interactions between nitrate and ammonium uptake in Chattonella antiqua. J. Oceanogr. Soc. Japan 41:33-38

Nakamura, Y., Watanabe, M. M. (1983a). Growth characteristics of Chattonella antiqua Part. 2. Effects of nutrients on growth. J. Oceanogr Soc. Japan. 39:151-155

Nakamura, Y., Watanabe, M. M. (1983b). Nitrate and phosphate uptake kinetics of Chattonella antiqua grown in light/dark cycles. J. Oceanogr. Soc. Japan. 39:167-170

Nalewajko, C., Garside, C. (1983). Methodological problems in the simultaneous assessment of photosynthesis and nutrient uptake in phytoplankton as functions of light intensity and cell size. Limnol Oceanogr 28:591-597

Nelson, D. M., Conway, H. L. (1979). Effects of the light regime on nutrient assimilation by phytoplankton in the Baja California and northwest Africa upwelling systems. J. mar Res. 37:301-318

Ohmori, M., Ohmori, K., Strotmann, H. (1977). Inhibition of nitrate uptake by ammonia in a blue-green alga, Anabaena cylindrica. Arch. Microbiol. 114:225-229

Olson, R. J. (12980). Nitrate and ammonium uptake in Antarctic waters. Limnol. Oceanogr. 25:1064-1074

Paasche, $E$ 11971). Effect of ammonium and nitrate on growth, photosynthesis, and carboxylase content of Dunaliella tertiolecta. Physiol. Plant. 25:294

Paasche, E. (1988). Pelagic primary production in nearshore waters. In: Blackburn, T. H., Sorensen, J. (ed.) Nitrogen cycling in coastal marine environments. John Wiley and Sons, New York, p. 33-57

Paasche, E., Bryceson, I., Tangen, K. (1984). Interspecific variation in dark nitrogen uptake by dinoflagellates. J. Phycol. $20: 394-401$

Paasche, E. Kristiansen, S. (1982). Nitrogen nutrition of phytoplankton in the Oslofjord. Estuar. coast. Shelf. Sci. 14:237249

Parslow, J. S., Harrison, P. J., Thompson, P. A. (1984). Saturated uptake kinetics: transient response of the marine diatom Thalassiosira pseudonana to ammonium, nitrate, silicate or phosphate starvation. Mar. Biol. 83:51-59

Pennock, J. R. (1987). Temporal and spatial variability in phytoplankton ammonium and nitrate uptake in the Delaware estuary. Estuar coast. Shelf Science. 24:841-857

Pinter, I. J., Provasoli, L. (1958). Artificial cultivation of a redpigmented marine blue-green alga. J. gen. Microbiol. 1.8:190-197

Price, N. M., Cochlan, W. P., Harrison, P. J. (1985). Time course of uptake of inorganic and organic nitrogen by 
phytoplankton in the Strait of Georgia: comparison of frontal and stratified communities. Mar. Ecol. Prog. Ser $27: 39-53$

Priscu, J. C., Priscu, L. R. (1984). Inorganic nitrogen uptake in oligotrophic Lake Taupo, New Zealand. Can. J. Fish. Aquat. Sci. 41:1436-1445

Priscu, J. C., Vincent, W. F., Howard-Williams, C. (1989). Inorganic nitrogen uptake and regeneration in perenially ice-covered Lakes Fryxell and Vanda, Antarctica. J. Plankton Res. 11:335-351

Probyn, T. A. (1985). Nitrogen uptake by size-fractionated phytoplankton populations in the southern Benguela upwelling system. Mar. Ecol. Prog. Ser. 22:249-258

Probyn, T. A. (1988). Nitrogen utilization by phytoplankton in the Namibian upwelling region during an austral spring. Deep Sea Res. 35:1387-1404

Probyn, T. A., Painting, S. J. (1985). Nitrogen uptake by sizefractionated phytoplankton populations in Antarctic surface waters. Limnol. Oceanogr. 30:1327-1332

Prochazkova, L., Blazka, P., Kraeva, M. (1970). Chemical changes involving $\mathrm{N}$ metabolism in water and particulate matter during primary production experiments. Limnol. Oceanogr. 15:797-807

Quéguiner, B., Hafsaoui, M., Treguer, P. (1986). Simultaneous uptake of ammonium and nitrate by phytoplankton in coastal ecosystems. Estuar. coast. Shelf Sci. 23:751-757

Rhee, G. Y., Lederman, T C. (1983). Effects of nitrogen sources on P-limited growth of Anabaena flos-aquae. J. Phycol. 19:179-185

Ricketts, T. R. (1988). Homeostasis in nitrogenous uptake/ assimilation by the green alga Platymonas (Tetra selmis) striata (Prasinophyceae). Ann. Bot. 61:451-458

Rigano, C., Rigano, V di M., Vona, V., Fuggi, A. (1981). Nitrate reductase and glutamine synthetase activities, nitrate and ammonia assimilation, in the unicellular alga Cyanidium calderium. Arch. Microbiol. 129:110-114

Robert, J. M., Maestrini, S. Y (1986). Absorptions simultanées des ions $\mathrm{NO}_{3}$ et $\mathrm{NH}_{4}^{+}$par trois diatomées de claires à huitres, en culture axenique. Phycologia 25:152-159

Rönner, V., Sorensson, F., Holm-Hansen, O. (1983). Nitrogen assimilation by phytoplankton in the Scotian Sea. Polar Biol. 2:137-147

Sahlsten, E. (1987). Nitrogenous nutrition in the euphotic zone of the central North Pacific gyre. Mar. Biol. 96:433-439

Sahlsten, E., Sörensson, F., Pettersson, K. (1988). Planktonic nitrogen uptake in the south-eastern Kattegat. J. exp. mar Biol. Ecol. 121:227-246

Samejima, H., Myers, J. (1958). On the heterotrophic growth of Chlorella pyrenoidosa. J. gen. Microbiol. 18:107-117

Serra, J. L., Llama, M. J, Cadenas, E. (1978). Nitrate utilization by the diatom Skeletonema costatum. I. Kinetics of nitrate uptake. Plant Physiol. 62:987-990

Sorrensson, F., Sahlsten, E. (1987). Nitrogen dynamics of a cyanobacterial bloom in the Baltic Sea: new vs. regenerated production. Mar. Ecol. Prog. Ser. 37:277-284

Syrett, P. J. (1981). Nitrogen metabolism of microalgae. In: Platt, T. (ed.) Physiological bases of phytoplankton ecol-

This review was submitted to the editor ogy, Bull. No. 210, Canadian Government Publishing Center, Hull, Quebec, Canada, p. 182-210

Takahashi, M., Saijo, Y. (1981). Nitrogen metabolism in Lake Kizaki, Japan. 1. Ammonium and nitrate uptake by phytoplankton. Arch. Hydrobiol 91:393-407

Terlizzi, D. E., Jr, Karlander, E. P. (1980). Growth of a coccoid nanoplankter (Eustigmatophyceae) from the Chesapeake Bay influenced by light, temperature, salinity, and nitrogen source in factorial combination. J. Phycol. 16:364-368

Terry, K. L. (1982). Nitrate uptake and assimilation in Thalassiosira weissflogii and Phaeodactylum tricornutum: interactions with photosynthesis and with uptake of other ions. Mar Biol. 69:21-30

Thacker, A., Syrett, P. J. (1972). The assimilation of nitrate and ammonium by Chlamydomonas reinhardi. New Phytol. $71: 423-433$

Thomas, R. J., Hipkin, C. R., Syrett, P. J. (1976). The interaction of nitrogen assimilation with photosynthesis in nitrogen deficient cells of Chlorella. Planta 133:9-13

Thompson, P. A., Levasseur, M. E., Harrison, P. J. (1989) Light-limited growth on nitrate vs. ammonium: what is the advantage for marine phytoplankton. Limnol. Oceanogr 34:1014-1024

Tischner, R. (1981). The regulation of the nitrate metabolism in Chlorella sorokiniana. Ber. dt. bot. Ges. 94S:635-645

Toetz, D. W (1981). Effect of $\mathrm{pH}$, phosphate and ammonia on the rate of uptake of nitrate and ammonia by freshwater phytoplankton. Hydrobiologia 76:23-26

Ward, A. K., Wetzel, R. G. (1980). Interactions of light and nitrogen source among planktonic blue-green algae. Arch Hydrobiol. 90:1-25

Warfar, M. V. M., Le Corre, P., Birrien, J. L. (1983). Nutrients and primary production in permanently well-mixed temperate coastal waters. Estuar. coast. Shelf Sci. 17:431-446

Whalen, S. C., Alexander, V (1984). Influence of temperature and light on rates of inorganic nitrogen transport by algae in an Arctic lake. Can. J. Fish. Aquat. Sci. 41:1310-1318

Whalen, S. C., Alexander, V (1986). Seasonal inorganic carbon and nitrogen transport by phytoplankton in an Arctic lake. Can. J. Fish. Aquat. Sci. 43:1177-1186

Wheeler, P. A., Kirchman, D. L. (1986). Utilization of inorganic and organic nitrogen by bacteria in marine systems. Limnol. Oceanogr. 31:998-1009

Yin, K. (1988). The interaction between nitrate and ammonium uptake for a marine diatom grown under different degrees of light limitation. M.Sc. thesis, University of British Columbia, Vancouver

Zevenboom, W., de Groot, G. J., Mur, L. R. (1980). Effects of light on nitrate-limited Oscillatoria agardhii in chemostat culture. Arch. Microbiol. 125:59-65

Zevenboom, W., Mur, L. R. (1981a). Simultaneous short-term uptake of nitrate and ammonium by Oscillatoria agardhii grown in nitrate- or light-limited continuous culture. J. gen. Microbiol. 126:355-363

Zevenboom, W., Mur, L. R. (1981). Ammonium-limited growth and uptake by Oscillatoria agardhii in chemostat cultures. Arch. Microbiol. 129:61-66

Manuscript first received: October 20, 1989

Revised version accepted: December 14, 1989 